\title{
Slaughter Conditions and Slaughtering of Pregnant Cows in Southeast Nigeria: Implications to Meat Quality, Food Safety and Security
}

\author{
Ugochinyere J. Njoga ${ }^{1}\left(\mathbb{D}\right.$, Emmanuel O. Njoga ${ }^{2, *}{ }^{\infty}$, Obichukwu C. Nwobi ${ }^{2}$, Festus O. Abonyi ${ }^{3}$, Henry O. Edeh ${ }^{4}$, \\ Festus E. Ajibo ${ }^{5}$, Nichodemus Azor ${ }^{5}$, Abubakar Bello ${ }^{6, *}$, Anjani K. Upadhyay ${ }^{7}$, \\ Charles Odilichukwu R. Okpala ${ }^{8, * \mathbb{C}}$, Małgorzata Korzeniowska ${ }^{8}{ }^{(\mathbb{D}}$ and Raquel P. F. Guiné ${ }^{9, *}$
}

1 Department of Veterinary Obstetrics and Reproductive Diseases, Faculty of Veterinary Medicine, University of Nigeria, Nsukka 410001, Nigeria; ugochinyere.njoga@unn.edu.ng

2 Department of Veterinary Public Health and Preventive Medicine, Faculty of Veterinary Medicine, University of Nigeria, Nsukka 410001, Nigeria; obichukwu.nwobi@unn.edu.ng

3 Department of Animal Health and Production, Faculty of Veterinary Medicine, University of Nigeria, Nsukka 410001, Nigeria; festus.abonyi@unn.edu.ng

4 Department of Animal Science, Faculty of Agriculture, University of Nigeria, Nsukka 410001, Nigeria; henry.edeh@unn.edu.ng

check for updates

Citation: Njoga, U.J.; Njoga, E.O.; Nwobi, O.C.; Abonyi, F.O.; Edeh H.O.; Ajibo, F.E.; Azor, N.; Bello, A.; Upadhyay, A.K.; Okpala, C.O.R.; et al. Slaughter Conditions and Slaughtering of Pregnant Cows in Southeast Nigeria: Implications to Meat Quality, Food Safety and Security. Foods 2021, 10, 1298 https://doi.org/10.3390/ foods10061298

Academic Editors: António Raposo, Renata Puppin Zandonadi and Raquel Braz Assunção Botelho

Received: 28 April 2021

Accepted: 3 June 2021

Published: 5 June 2021

Publisher's Note: MDPI stays neutral with regard to jurisdictional claims in published maps and institutional affiliations.

Copyright: (C) 2021 by the authors Licensee MDPI, Basel, Switzerland. This article is an open access article distributed under the terms and conditions of the Creative Commons Attribution (CC BY) license (https:// creativecommons.org/licenses/by/ $4.0 /)$
Department of Animal Health and Production, Enugu State Polytechnic, Iwollo 401139, Nigeria; ejikeajibo5@gmail.com (F.E.A.); azornichodemus@gmail.com (N.A.)

6 Faculty of Veterinary Medicine, Wroclaw University of Environmental and Life Sciences, 50-375 Wrocław, Poland

7 Heredity Healthcare \& Lifesciences, 206-KIIT TBI, Patia, Bhubaneswar, Odisha 751024, India; upadhyayanjanikumar6@gmail.com

8 Faculty of Biotechnology and Food Sciences, Wroclaw University of Environmental and Life Sciences, 50-375 Wroclaw, Poland; malgorzata.korzeniowska@upwr.edu.pl

9 CERNAS Research Centre, Polytechnic Institute of Viseu, 3504-510 Viseu, Portugal

* Correspondence: njoga.emmanuel@unn.edu.ng (E.O.N.); abubakar.bello@upwr.edu.pl (A.B.); charlesokpala@gmail.com (C.O.R.O.); raquelguine@esav.ipv.pt (R.P.F.G.)

\begin{abstract}
The increase in the slaughter of pregnant cows (SPCs) for meat (except as may be approved by veterinarians on health grounds to salvage the animal) is unethical. SPCs for meat is also counterproductive, detrimental to food security, and may enhance zoonotic disease transmission. In this context, therefore, this current study examined slaughter conditions and the slaughtering of pregnant cows, and the implications for meat quality, food safety, and food security in Southeast Nigeria. The direct observational method was employed to examine the slaughterhouse activities, from when the cattle arrived at the lairage to the post-slaughter stage. A pre-tested and validated closed-ended-questionnaire was used to elicit information on causes of the SPCs and the method of disposal of eviscerated foetuses. Pregnancy status of cows slaughtered was determined by palpation followed by visual examination of the eviscerated and longitudinal incised uteri. The study lasted for six months during which 851 cows out of 1931 slaughtered cattle were surveyed. Assessment/decision-making protocol of slaughterhouse conditions, welfare conditions of slaughtercattle, reasons for sale or slaughter of pregnant cows, distribution of pregnant cows slaughtered, method of disposal of eviscerated foetuses, and estimated economic losses of SPCs were delineated. Of the 851 cows examined, $17.4 \%$ (148/851) were pregnant while $43.2 \%(64 / 148)$ of the total foetuses recovered were in their third trimester. Major reasons adduced for SPCs by proportion of involved respondents were: ignorance of the animals' pregnancy status $(69.7 \%, 83 / 119)$, high demand for beef (61.3\%, 73/119), preference for large-sized cattle (47.9\%, 57/119), economic hardship $(52.1 \%, 62 / 119)$ and diseases conditions (42.9\%. 51/119). The conduct of SPCs for meat would not be profitable. This is because within six months, an estimated loss of about $44,000 \mathrm{~kg}$ of beef, equivalent to 70.1 million or $\$ 186,400$ would be associated with SPCs and the consequential foetal wastages. If losses were to be replicated nationwide across slaughterhouses, 4.3 tons of beef estimated at 8.6 billion or $\$ 23$ million would be wasted. Improving slaughter conditions and the welfare of slaughter-cattle in Nigerian slaughterhouses through advocacy, training of slaughterhouse workers, and strict implementation of
\end{abstract}


laws promoting humane slaughter practices is imperative. Preventing SPCs for meat and inhumane slaughter practices at the slaughterhouse would enhance the welfare needs of slaughter cattle, grow the national herd size, and improve meat safety as well as food security.

Keywords: animal welfare; bovine foetal wastage; food safety and security; meat quality; national herd size; slaughter of pregnant cows

\section{Introduction}

Globally, achieving high-level beef/meat quality from any given cattle slaughterhouse requires that optimum levels of good practices must be upheld. Regardless of location, cattle pre-slaughter and slaughter operations remain very critical to meat quality and food security [1-3]. There are pre- and post-slaughter conditions/factors in slaughterhouses that influence meat quality and food security. For instance, pre-slaughter factors include high animal density during transport, inadequate lairage facilities at the slaughterhouse, long-distance travel, (poor) handling practices during loading and unloading and during transport, as well as unskilled drivers [4-7]. On the other hand, post-slaughter factors include humidity, temperature, meat $\mathrm{pH}$, microbial contamination and storage time, which would affect the keeping and nutritional qualities of the meat [8]. Moreover, the welfare of animals at slaughter indeed affects meat quality, which undermines food safety, public health, and economic viability in meat production or processing enterprises [2,9]. Additionally, the stress inflicted during slaughter can change the meat characteristics [10-12]. Further, bad slaughter management operations can decrease carcass quality, which could arise because of cross-contamination [2,13]. Some carcass/meat defects caused by preslaughter stress or poor welfare conditions are Pale, Soft, Exudative (PSE) and Dark Firm and Dry (DFD) meats $[14,15]$. Humane handling of slaughter-cattle prohibits cruel practices such as dragging, dropping, throwing or hoisting during the slaughter process [16]. Factors that are used to evaluate compliance to humane slaughter practices include the proportion of the slaughter animals that: (a) were successfully stunned at the first attempt; (b) were rendered unconscious post first stunning; (c) vocalised during stunning and bleeding; (d) fall during handling; and (e) moved with an electric goad [16,17].

Animal welfare (AW) refers to the overall well-being of non-human animals, especially domesticated/farmed animals reared for companionship and food (meat) production [18]. Typically, an animal is considered to be in a good state of welfare when it is healthy and well-nourished, under zero pain, distress or fear, and able to easily express its instinctive behaviour [18]. Good AW, among other things, requires the provision of appropriate feed and shelter, humane handling, and humane slaughter [19]. The principles of AW permit responsible use of animals for human benefits (companionship, food, recreation and work), but such animals must be protected and cared for in a manner that minimises fear, pain, stress, and suffering [20]. In Nigeria, the Department of Veterinary and Pest Control Services (DVPCS) is responsible for protection and promotion of AW. Actually, the DVPCS in Nigeria is under the supervision of the Chief Veterinary Officer (CVO), who also functions as the World Organisation for Animal Health delegate. The CVO oversees animal health and welfare issues, well known to involve: (a) animal disease prevention and control; (b) prevention of the slaughter of gravid animals (unless approved by an accredited veterinary doctor); and (c) humane animal handling/slaughter practices.

Adherence to AW standards, other than an ethical issue, may enhance the microbiological safety of beef and beef products, and therefore protect the consumers from infections with zoonotic pathogens. Stress factors and poor AW can increase susceptibility of slaughter-cattle, especially the pregnant ones, to diseases which may be zoonotic and hence transmissible to humans via the food chain [21]. Globally, approximately $600 \mathrm{mil}-$ lion foodborne illnesses and 420,000 deaths have annually been attributed to microbial pathogens, largely owed to poor food (as well as meat) processing practices [9]. Through 
the provisions of the Meat Edict of 1968 in Nigeria, the slaughter of pregnant female animals (PFAs) is prohibited, so as to improve AW and conserve livestock resources. This specific edict equally forbids the slaughter of gravid animals, with the exception of emergency slaughter. The purpose for this is to relieve animal suffering, and this has to be recommended by a veterinarian. Despite the obsolete nature of this edict, maternal slaughter and the resultant foetal wastage has continued unabated [22-24]. The reason for this could also be attributed to the poor implementation of this edict. Moreover, the immediate cause(s) of this menace (maternal slaughter) still remains elusive. This may be due to the upsurge in the demand for edible animal products in Nigeria [25], occasioned by the rapidly increasing human population, currently estimated at 210 million, which is based on a $3.5 \%$ annual growth rate [26].

Besides animal cruelty, the slaughter of pregnant female animals (PFAs) remains counterproductive, threatens food security, and exerts immense loss in livestock revenue/resources [27-30]. Slaughter of pregnant cows (SPCs) would not only depopulate productive female animals, but also depletes future herds via consequential foetal wastages. As such, this would jeopardise efforts towards achieving self-sufficiency in provision of enough edible animal protein, especially in developing countries [31]. SPCs could lead to the introduction of exotic zoonoses (bovine spongiform encephalopathy and variant Creutzfeldt-Jakob disease) through meat importation due to deficits in animal protein occasioned by excessive off-takes from the national herd [31]. In developing countries, the diminution of animal protein is a major public health problem associated with the slaughter of PFAs [32], which may ensue through the unwarranted off-takes from the national herd without commensurate replacement, as epitomised in SPCs and the consequential bovine foetal wastages. Despite the fact that SPCs and associated AW and economic implications are preventable, the practice regrettably persists in Nigeria [24,33-37], where demand for edible animal products incidentally supersedes the supply [38,39].

SPCs appears to increasingly be the status quo, despite the fact that unauthorised slaughter of gravid females for meat connotes animal cruelty and counteracts the growth of the national herd. Therefore, determining the current status and its underpinning drivers are warranted considering that the last available report on SPCs in South-East Nigeria is over three decades old [40]. Additionally, it appears there is no published report/pathway to determine the conditions/welfare of both slaughtered cattle/slaughterhouses in Nigeria. Additionally, knowing the number of pregnant cattle slaughtered for meat may provide useful clues on slaughterhouses' compliance to AW needs, especially in Nigeria. Further, determining the root-causes of SPCs will guide informed decision making regarding improved AW, growing the national cattle herd size and boosting the livestock economy in Nigeria. To supplement existing literature, therefore, this current study examined the slaughter conditions and slaughtering of pregnant cows, and the implications for meat quality, food safety, and food security in South-East Nigeria.

\section{Materials and Methods}

\subsection{Area/Location of Study}

The demographics, climatic and orographic conditions of South-East Nigeria, the study location, have been previously described [41,42]. The South-East is one of the six geopolitical zones of Nigeria that consists of five states-Abia, Anambra, Ebonyi, Enugu and Imo (Figure 1). The zone is located on latitude $5^{\circ} 45^{\prime} 00^{\prime \prime} \mathrm{N}$ and longitude $8^{\circ} 30^{\prime} 00^{\prime \prime} \mathrm{E}$. The South-East zone has a total land area of about $40,000 \mathrm{~km}^{2}$, and borders Cameroon at the Eastern boundary. The region had an estimated population of about 40 million people in 2019 [43], but realistically the population is now approximately 60 million. The population density of the South-East ranges from 140 to 390 persons per $\mathrm{km}^{2}$ (depending on the state or town), as against Nigeria's average population density of 226 per $\mathrm{km}^{2}$; making the zone one of the most densely populated regions in Africa. 


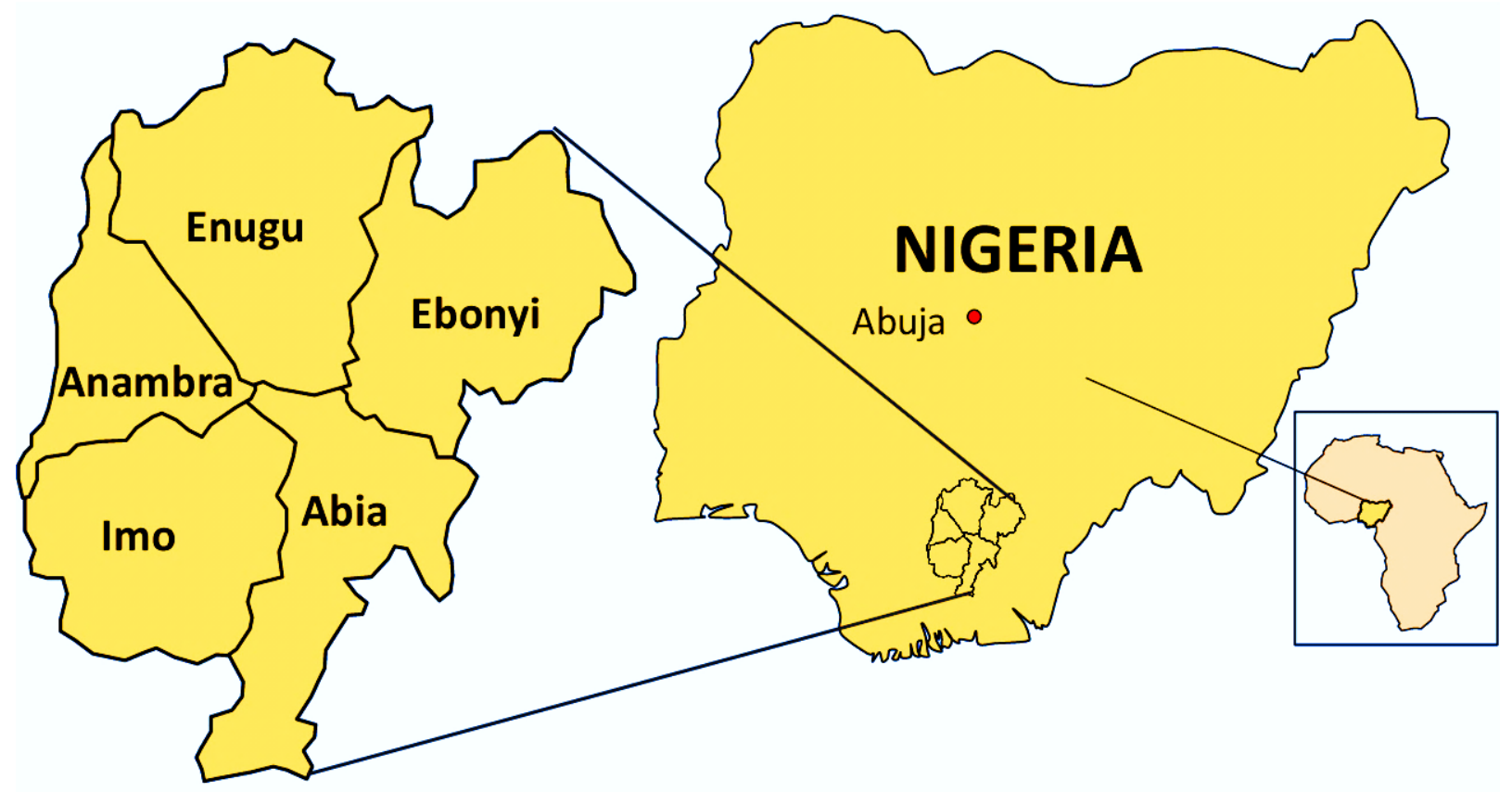

Figure 1. Map of the study area, the South-East geopolitical zone of Nigeria, showing the positions of the zone in African and Nigerian maps, and the constituent five Nigerian states that comprise the South-Eastern part.

\subsection{Schematic Overview of the Experimental Program}

The schematic overview of the experimental program, from the study design to the age estimations and disposal of eviscerated bovine foetuses from major slaughter facilities in South-East Nigeria, is shown in Figure 2. For emphasis, this current study was designed to examine how slaughter conditions and slaughtering of pregnant cows impact on the meat quality, food safety, and food security, with specific reference to the South-Eastern part of Nigeria. The study adopted a cross-sectional study design which consisted of two phases. The first was the pathway determination of the status of slaughter-cattle, from the process of off-loading, to the period of waiting at the lairage, and during slaughter. This was conducted by direct observational methods, as described by Holmes [44]. The second was determination of the prevalence and causes of SPCs in the study area. Three major slaughter facilities in the study area, Nsukka, Kwata and Akwata slaughterhouses, being the major slaughterhouses with a combined slaughter capacity of about $70 \%$ of all cattle consumed in the zone [45], were purposively selected for the study.

\subsection{Ethical Approval}

Institutional ethics approval was deemed not necessary for this survey activity. This is because the researchers did not slaughter the cattle surveyed, but only examined slaughtered pregnant cows during routine meat/carcass inspection activities performed at the studied slaughterhouses. Pre-slaughter conditions of the animals were determined by direct observational study, and there was no physical restraint/handling of the live animals by the researchers. However, the slaughterhouses' associations approved the use of the research instrument (i.e., questionnaire) prior to the survey. Importantly, given that the survey involved interviews of slaughterhouse workers, informed consent was orally obtained prior to their participation. Additionally, this study adhered to the code of ethics of the World Medical Association Declaration of Helsinki [46], and the participation of every respondent included in this survey was entirely voluntary. 


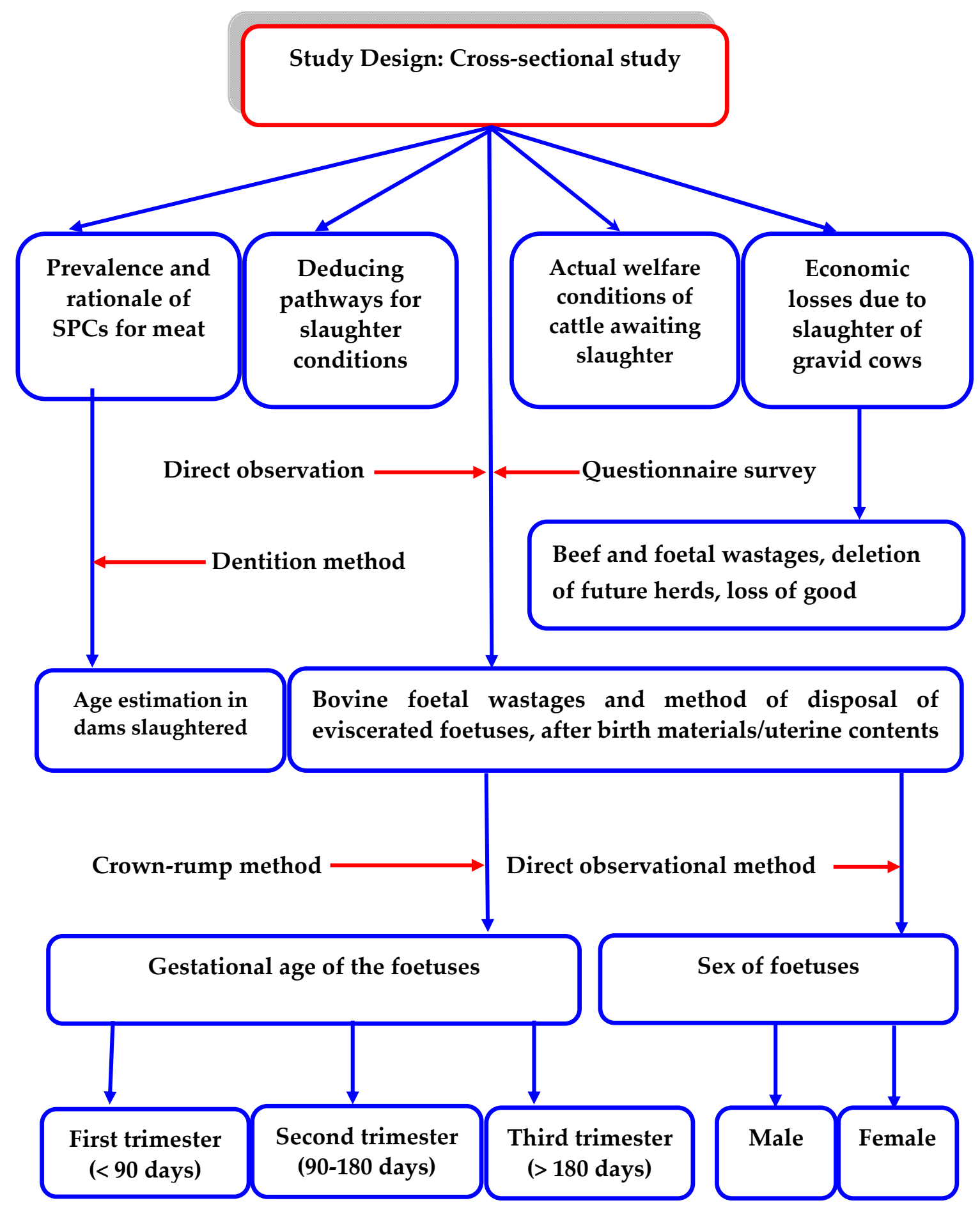

Figure 2. The schematic overview of the experimental program, from the study design, to the age estimations, and the disposal of eviscerated bovine foetuses from major slaughter facilities in South-East Nigeria.

\subsection{Research Visits and Sample Size Determination}

The selected slaughterhouses were visited weekly, precisely on Saturdays (as more cattle are usually slaughtered on weekends) for six months, (three months during the dry/hot season and another three months during the wet/rainy season) for data collection. A minimum sample size of 385 cows was calculated for the study on pregnancy status of slaughter-cattle, using the formula: $n=\mathrm{Z}^{2} \mathrm{P}(1-\mathrm{P}) / \mathrm{d}^{2}$; where $n=$ required sample size, $\mathrm{Z}=$ normal deviate (1.96) at $5 \%$ significance level, and $\mathrm{P}=$ assumed prevalence of bovine foetal wastages (BFW). The sample size calculation was based on a $50 \%$ estimated 
prevalence, as described by Pourhoseingholi and other workers [47], since there is no published report, to the best of knowledge, on BFW in South-East Nigeria. However, for accuracy and buoyancy of data, a total of 851 cows out of 1931 slaughtered cattle surveyed during the six month period, were selected by simple random sampling technique (toss of coin) in this study.

\subsection{Development and Validation of Research Instrument}

The research instrument took the form of a structured and pre-tested closed-ended questionnaire. This was used to elicit information underscoring the SPCs and its implications on the meat quality, food safety and security. Specifically, the questionnaire structure had two parts. One part sought to ascertain the pathways to determine the slaughter conditions/welfare. This involved questions that aimed to reveal the major steps followed prior to decision-making about welfare conditions within the studied slaughterhouses. The other part sought to ascertain the possible causes of SPCs and method of disposal of eviscerated foetuses or gravid uterine contents, from which implications of SPCs on the meat quality, food safety and security could be deciphered. This involved questions that aimed to reveal the reasons for sale or slaughter of pregnant cows, distribution of pregnant cows slaughtered, the method of disposal of eviscerated foetuses, and the estimated economic losses of SPCs.

The initial draft questionnaire was subjected to face and content validations consistent with the method described by Bolarinwa [48]. Thereafter, it was pilot tested on 20 respondents in order to detect and correct possible errors that may arise during the actual survey process. Additionally, Cronbach's alpha test was performed to ascertain the reliability of the data/questionnaire in determining the parameters of interest, using IBM ${ }^{\circledR}$ SPSS statistics version 25 (SPSS Inc., Chicago, IL, USA). The test yielded a reliability coefficient (alpha value) of 0.841 (which was $\geq 0.7$ ), and therefore ascertained the questionnaire reliable and valid, and ready for this current work.

\subsection{Administration of Research Instrument}

A total of 119 slaughterhouse workers, selected from a sampling frame of 356 workers, across the three selected slaughterhouses, participated in the study. The slaughterhouse workers surveyed included butchers, cattle dealers/marketers, animal attendants (herders) and meat sellers. These workers performed various roles, one complementing the other in some cases. For instance, a butcher could be herding the cattle after abattoir operations. In another instance, the cattle marketers may butcher the slaughtered animals and also sell the meat themselves. A simple random sampling technique (toss of coin) was used to select the 119 respondent from over 200 slaughterhouse workers, who willingly volunteered to partake in the survey.

The questionnaire survey was conducted during each visit. The survey was conducted in the form of an interview, and the responses recorded accordingly. The veterinarian and an assistant would ask questions from the questionnaire, and the slaughterhouse worker would provide answers. In some cases where respondents were unable to fully understand the question posed in the English language, the native language was used without change of content or context, but to enhance participation, ensure least pressure (to the respondent), and elicit appropriate response. Utmost care was taken to ensure that each respondent was not surveyed more than once.

\subsection{Elaboration of Questionnaire Parameters}

\subsubsection{Pathways to Determine the Slaughter Conditions}

The task here was to determine what would eventually be called "assessment/decisionmaking protocol of slaughterhouse conditions/welfare". This would help identify and subsequently establish in logical sequence the steps that would lead to decision-making as regards conditions/welfare of slaughterhouses. This involved questions aimed to delineate major factors that could serve as checks, as well as help establish right decisions 
regards the condition/welfare of the slaughterhouse. Brainstorming sessions with (slaughterhouse) workers, together with the veterinarians that conducted the study, would enable deductions/reflections on the positive and negative welfare conditions, to proffer potential way-outs.

\subsubsection{Pregnancy Status of the Selected Slaughtered Cows}

The pregnancy status of the selected slaughtered cows was ascertained by visual inspection and palpation of the uteri and the uterine horns for gross/macroscopic evidence(s) of pregnancy. The uteri and the horns were eviscerated post slaughter, longitudinally incised, and then systematically and thoroughly inspected (post-mortem) for evidence of pregnancy (presence of membrane slip, foetus/foetuses, placentation, placentome-foetal cotyledon and maternal caruncle or other afterbirth materials). The ages of the dams were estimated by the dentition method as described by Pace and Wakeman [49]. For the foetuses, estimation of the gestational age was performed by crown-rump length measurement using the formula: $X=2.5(Y+21)$; where $X=$ age of the foetus in days and $Y=$ crown-rump length in $\mathrm{cm}$ as described by Kouamo and other researchers [50]. Thereafter, the gestational age of the recovered foetuses were categorised as first ( $<90$ days), second ( $90-180$ days) or third (>180 days) trimester. Similarly, sex of the foetuses was determined by visual examination of the external genitalia at the inguinal region or below the base of the tail.

\subsubsection{Estimated Loses of Beef from Slaughtered Pregnant Cows (SPCs)}

Losses in beef production associated with SPCs was estimated based on a $63 \%$ carcass yield [51], and an average maturity live weight of $460 \mathrm{~kg}$ per cattle, as described by Ndi and co-workers [52]. The estimation assumed that the 148 foetuses would be born alive and raised to maturity, but allowance for $5 \%$ pre-maturity mortality was factored in as recommended by Ndi and co-workers [52]. Additionally, the associated economic losses were determined by mark-up pricing methods, as described by Crowson [53], using the prevailing price of beef in the local markets. The monetary value was estimated in Naira (N) and converted to US Dollars (\$) based on the current market price of $\sim \mathrm{N} 2000$ (roughly $\$ 5.3$ at the Central Bank of Nigeria (CBN) official exchange rate of 380 per US Dollar as of 01 April 2021) per kilo of beef.

\subsection{Statistical Analysis}

The resultant data were collated, analysed and presented in tables and figures. Fisher's exact test was used to determine whether there is significant association $(p \leq 0.05)$ between SPCs and seasons, age, breed, months of the year and slaughterhouse locations. The statistical significance was set at $p<0,05$ (95\% confidence interval). IBM ${ }^{\circledR}$ SPSS statistics version 25 (SPSS Inc., Chicago, IL, USA) was used to run the statistical analysis.

\section{Results}

\subsection{Establishing the Pathway of Slaughter Conditions/Welfare}

Brainstorming sessions with (slaughterhouse) workers, together with the veterinarians that conducted the study, enabled the deduction of the feasible pathway in regard to the slaughterhouse conditions/welfare decision-making activity. The schematic diagram of assessment/decision-making protocols of slaughterhouse conditions/welfare is shown in Figure 3. It shows the major steps, from the assembly of the animal welfare team, to the actual decision-making actions. Table 1 shows the considerations of cattle slaughter conditions/welfare and corresponding way-outs, from environment at the lairage, to during the slaughter of cattle. The considerations of cattle slaughter conditions/welfare were either positive or negative. The way-outs were aimed to alleviate the negative (and strengthen the positive) decision-making. 


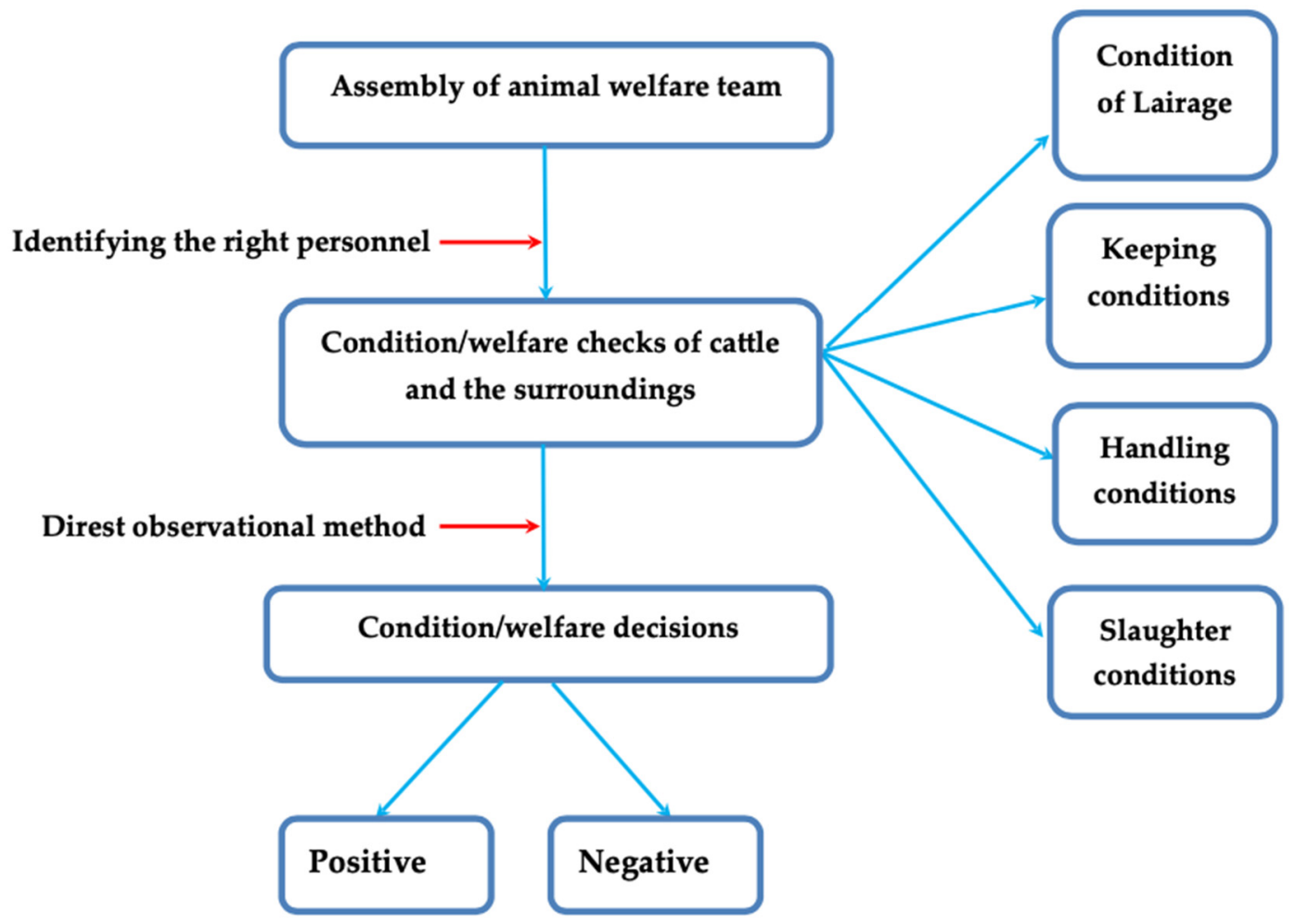

Figure 3. A schematic flow of assessment/decision-making protocol of slaughterhouse conditions/welfare.

Table 1. Positive and negative cattle welfare conditions and corresponding way-outs, from environment conditions at the lairage, up to the actual slaughter process/practices.

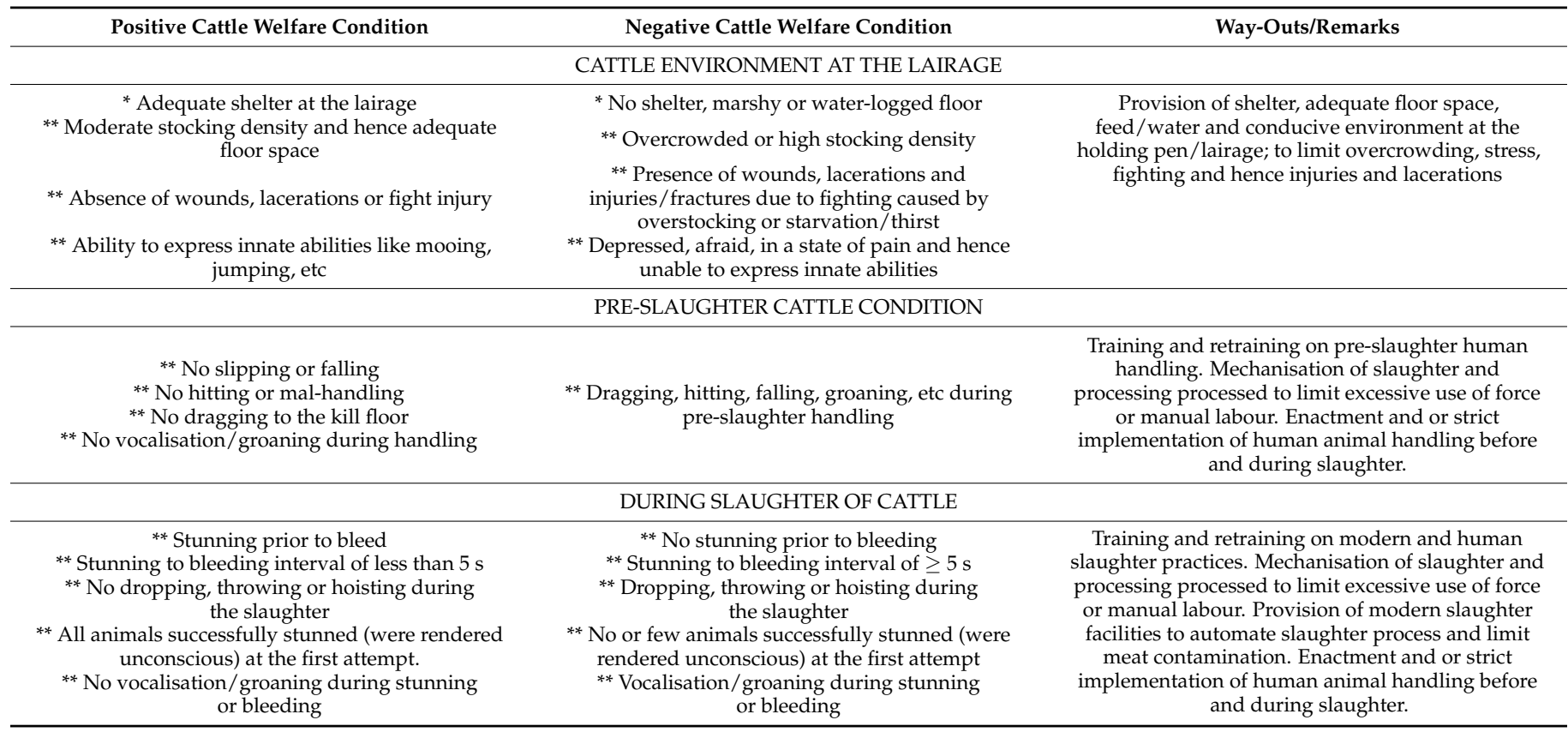

*Veterinarians' field experience; ** Sourced from published works [2,16,54-56].

\subsection{Reasons for Sale or Slaughter of Pregnant Cows}

The reasons for sale or slaughter of pregnant cows for meat among herders and abattoir workers in South-Eastern Nigeria are shown in Table 2. Some of the reasons for SPCs and a proportion of the respondents were: ignorance of the animals' pregnancy status $(69.7 \%, 83 / 119)$, high demand for beef $(61.3 \%, 73 / 148)$, buyers' preference for large-sized 
animals $(47.9 \%, 57 / 148)$, feed scarcity during drought $(26.9 \%, 32 / 148)$, economic hardship $(52.1 \%, 62 / 148)$ and disease conditions $(42.9 \%, 51 / 148)$.

Table 2. Reasons for sale or slaughter of pregnant cows for meat among herders and abattoir workers $(n=119 *)$ in South-Eastern Nigeria.

\begin{tabular}{cccc}
\hline & \multicolumn{2}{c}{ Number (\%) of Respondents } \\
\cline { 2 - 4 } Reasons/Causes & Yes & No & No Response \\
\hline High demand for beef & $73(61.3)$ & $21(17.6)$ & $25(21.0)$ \\
Economic hardship & $62(52.1)$ & $57(47.9)$ & 0 \\
Ignorance of the pregnancy status of the animal & $83(69.7)$ & $32(26.9)$ & $4(3.4)$ \\
Preference for pregnant cows because of size & $57(47.9)$ & $46(38.7)$ & $16(13.4)$ \\
Feed scarcity during dry seasons & $32(26.9)$ & $87(73.1)$ & 0 \\
Disease conditions & $51(42.9)$ & $42(35.3)$ & $26(21.8)$ \\
\hline
\end{tabular}

* Total number of herders and abattoir workers in the 3 slaughterhouses surveyed.

\subsection{Distribution of Pregnant Cows Slaughtered}

The age, season and breed distribution of pregnant cows $(n=148)$ slaughtered in South-East Nigeria is shown in Table 3. The spatial and temporal distribution of pregnant cows $(n=148)$ slaughtered in major slaughterhouses in South-East Nigeria is shown in Table 4 . The number of cows slaughtered statistically differed across the age groups $(p=0.029)$ and season $(p=0.038)$, but not breed $(p>0.05)$. The majority of the slaughtered pregnant cows $(60.1 \%=$ prevalence) were in their active reproductive age (4-8 years). Approximately 59\% (87/148) of the pregnant animals were slaughtered during the dry/hot season. Most of the pregnant cows $(80.4 \%, 119 / 148)$ were of the White Fulani breed. The number of cows slaughtered statistically differed across the month of slaughter $(p=0.021)$, but not slaughter location $(p>0.05)$. Similarly, greater proportions $(34.5 \%)$ of the pregnant cows were slaughtered in December, while only 38.5\% (57/148) were killed at the Akwata slaughterhouse, located in Enugu State, Nigeria.

Table 3. Age, season and breed distribution of pregnant cows $(n=148)$ slaughtered in South-East Nigeria.

\begin{tabular}{ccccc}
\hline Variables & $\begin{array}{c}\text { Number (\%) of } \\
\text { Cows Slaughtered }\end{array}$ & $\begin{array}{c}\text { Number (\%) of Pregnant } \\
\text { Cows Slaughtered }\end{array}$ & Prevalence & $p$-Value \\
\hline AGE & $126(14.8)$ & $30(23.8)$ & 20.3 & $0.029^{*}$ \\
$<4$ years & $498(58.5)$ & $89(17.8)$ & 60.1 \\
4-8 years & $227(26.7)$ & SEASON & $29(12.8)$ & 19.6 \\
$>8$ years & $418(49.1)$ & $61(14.6)$ & 41.2 & $0.038^{*}$ \\
Wet & $433(50.9)$ & $87(20.1)$ & 58.8 & \\
Dry & $621(72.9)$ & $119(19.2)$ & 80.4 & 0.149 \\
White Fulani & $130(15.3)$ & $18(13.8)$ & 12.2 & \\
Sokoto gudali & $63(7.4)$ & $7(11.1)$ & 4.7 & 2.7 \\
Red bororo & $37(4.3)$ & $4(10.8)$ & & \\
Mixed breeds & & & & \\
\hline
\end{tabular}

* Significant statistical association $(p \leq 0.05)$, Fisher's exact test.

Table 4. Spatial and temporal distribution of pregnant cows $(n=148)$ slaughtered in major slaughterhouses in South-East Nigeria.

\begin{tabular}{|c|c|c|c|c|}
\hline Variables & $\begin{array}{l}\text { Number (\%) of } \\
\text { Cows Slaughtered }\end{array}$ & $\begin{array}{l}\text { Number (\%) of Pregnant } \\
\text { Cows Slaughtered }\end{array}$ & Prevalence & $p$-Values \\
\hline \multicolumn{5}{|c|}{ MONTHS } \\
\hline December & $197(23.1)$ & $51(25.9)$ & 34.5 & $0.021 *$ \\
\hline January & $157(18.4)$ & $24(15.3)$ & 16.2 & \\
\hline February & $129(15.2)$ & $21(16.3)$ & 14.2 & \\
\hline July & 118 (13.9) & $17(14.4)$ & 11.5 & \\
\hline August & $121(14.2)$ & $16(13.2)$ & 10.8 & \\
\hline September & $129(15.2)$ & $19(14.7)$ & 12.8 & \\
\hline \multicolumn{5}{|c|}{ SLAUGHTER LOCATIONS } \\
\hline Enugu & $327(38.4)$ & $57(17.4)$ & 38.5 & 0.406 \\
\hline Nsukka & $315(37.0)$ & 49 (15.6) & 33.1 & \\
\hline Awka & 209 (24.6) & $42(20.1)$ & 28.4 & \\
\hline
\end{tabular}

* Significant statistical association $(p \leq 0.05)$, Fisher's exact test. 
The age and sex distribution of foetuses $(n=148)$ recovered from pregnant cows slaughtered in South-East Nigeria is shown in Table 5. Furthermore, 55.4\% (82/148) of foetuses recovered were male, while 22.3\% (33/148), 34.5\% (51/148) and 43.2\% (64/148) were in their first, second and third trimester of gestation, respectively. Significant association ( $p \leq 0.05$ ) existed between SPCs and age and season at $p=0.029$ and 0.038 , respectively. In the same vein, there was significant association $(p \leq 0.05)$ between SPCs and months of the year, but none was found between SPCs and slaughterhouse location at $p=0.406$.

Table 5. Age and sex distribution of foetuses $(n=148)$ recovered from pregnant cows slaughtered in Southeast, Nigeria.

\begin{tabular}{ccc}
\hline Variables & Number (\%) of Foetuses \\
\hline First trimester & AGE & \\
Second trimester & & $33(22.3)$ \\
Third trimester & $51(34.5)$ \\
& SEX & $64(43.2)$ \\
Male & & $82(55.4)$ \\
Female & $66(44.5)$ \\
\hline
\end{tabular}

\subsection{Method of Disposal of Eviscerated Foetuses}

The method of disposal of eviscerated foetuses among abattoir workers $(n=119)$ surveyed in South-East Nigeria is shown in Table 6. Eviscerated foetuses or uterine contents were sold for human consumption, 17.6\% (21/119); preparation of dog food, $27.7 \%(33 / 119)$ or disposed by open refuse dump methods, 54.6\% (65/119). Likewise, $23.5 \%$ (28/119) of the slaughterhouse workers surveyed sold foetuses or afterbirth materials for the feeding of pigs or fish (Table 6). Only 5.9\% (7/119), and 3.4\% (4/119) of the respondents disposed the foetuses or afterbirth materials by burial and incineration, respectively.

Table 6. Method of disposal of eviscerated foetuses among abattoir workers $(n=119)$ surveyed in South-East Nigeria.

\begin{tabular}{cc}
\hline Method of Foetus Disposal * & Number (\%) of YES Respondents \\
\hline Sold foetuses for human consumption & $21(17.6)$ \\
Sold foetuses for preparation of dog food & $33(27.7)$ \\
Sold eviscerated foetus for feeding of fishes or pigs & $28(23.5)$ \\
Dumped unsold foetus or gravid uterine contents in & $65(54.6)$ \\
municipal refuse dump & $4(3.4)$ \\
Incinerated unsold foetus or gravid uterine tissues & $7(5.9)$ \\
\hline
\end{tabular}

* Many respondents disposed foetuses by more than one method.

\subsection{Estimated Economic Losses of SPCs}

As regards the economic losses inherent in SPCs and the consequential bovine foetal wastages, if the 148 foetuses were born alive and reared to maturity, this would have yielded $42,890 \mathrm{~kg}$ of beef (based on $63 \%$ carcass yield and average maturity live weight of $460 \mathrm{~kg}$ ). If the same numbers of foetuses were wasted in all of the slaughterhouses nationwide, 4.3 tons of beef would have been lost. In monetary terms (based on current market price of 2000 or $\$ 5.3$ per $\mathrm{kg}$ of beef), this would amount to a loss of 70.1 million $(\$ 186,400)$, which corresponds to a loss of 8.6 billion ( $\$ 23$ million) nationwide (data not shown). To estimate the annual economic losses associated in SPCs and the resultant foetal wastages, the aforementioned figures would have to be doubled, since the estimated losses were computed for just a period of six months in which the study lasted. 


\section{Discussion}

Identifying the right personnel, particularly with the appropriate experience, as shown in Figure 3, is very crucial in ensuring that the conditions/welfare checks of the cattle and its surroundings are adequately assessed. Additionally, from Figures 2 and 3, the direct observation method is adapted to help ensure that the final decision-making arrived at is evidence-based. Conditions of the lairage, keeping, handling and slaughter conditions are among the key factors deemed needful in ensuring that optimal welfare checks are adequate. On the other hand, Table 1 has elaborated positive and negative conditions foreseeable in various cattle slaughter situations. Particularly, the way-outs further substantiate how to ensure the authenticity, consistency and standardisation of decision-making. Implementing the decision-making strategy herein (refer to Figure 3 and Table 1) can help maintain humane slaughter practices of cattle thriving in slaughterhouses. To see that humane slaughter practices apply to the slaughter animals, some factors have to be considered, for example the number of cattle that: (1) were successfully stunned at the first attempt, (2) were rendered unconscious post first stunning, (3) vocalised during stunning and bleeding, (4) fall during handling, and (5) moved with an electric goad (where applicable) $[16,17]$. At the post-slaughter of cattle, there could arise carcass/meat defects such as PSE and DFD, which can be associated with an abnormal meat $\mathrm{pH}$. This generally happens when food-producing animals, prior to slaughter, are subject to poor welfare conditions [14]. Such meat defects pose detrimental effects to the quality indices, which impedes profitability and sustainability of any meat production enterprise [15]. Therefore, cruel practices like dragging, dropping, throwing or hoisting during the slaughter process should be prohibited, as it is not part of the humane handling practices [16]. Notably, poor AW together with stress factors can increase disease susceptibility of slaughter-cattle, especially the pregnant ones. Such disease conditions may be zoonotic, and hence transmissible to humans via the food chain [21].

The findings herein, that $17.4 \%$ of the cows slaughtered for meat were pregnant, is unacceptably high from AW and animal production perspectives (Table 3). This portends flagrant disregard and insensitivity to the welfare needs of the pregnant cows. To protect the welfare of pregnant animals, the Nigerian Meat Edict of 1968, the Animal Disease (Control) Act of 2004 (as amended), as well as the Council Regulation (No 1/2005) of the EU [57], prohibits the transportation of gravid animals, especially at the late stage of their gestation. The laws/regulations likely foresee that the welfare needs of the dam and that of their foetuses may not be met en route, due to the delicate nature of pregnant animals. Therefore, the SPCs only climaxed the abuse of the animals' welfare, which was violated $a b$ initio when the gravid dams were transported to the abattoirs for slaughter. Although Nigeria does not have a stand-alone legislation on the welfare of animals, legislations guiding the use and ownership of animals, whether in the form of Acts, Code, and Laws, of which some are considered obsolete, have been amended to promote AW. The development of the Nigerian Animal Welfare Strategy Framework in 2016 is one of such amendments. This welfare strategy, which applies to all domestic and captive animals, proscribes all forms of cruelty, deliberate pain or suffering to animals, through negligence or failure to act by the animal owners/custodians/care giver. Additionally, the Animal Disease (Control) Act of 2004 (as amended) provides some additional protections for farm animals, including limiting stocking density during transportation to ensure adequate ventilation. This specific Act also provides for feeding en route, for slaughter/trade animals transported over very long distances. However, there appears to be no significant progress, particularly to ensure the strict implementation of these legal statutes. The operationalisation of standard AW practices in Nigeria remains very challenging, because the nation's cattle production subsector is almost entirely in the hands of "Fulani" herdsmen, who engage in the nomadic system of cattle-rearing that involves (calves or pregnant cows) trekking over very long distances daily in search of food or water [58-60].

To actualise the effective implementation of humane slaughter practices in Nigerian slaughterhouses remains very challenging, largely due to the limited mechanised slaughter 
facilities [61]. Moreover, stunning prior to bleeding during the slaughter process can greatly reduce pain perception. However, the 'halal' slaughter widely practiced in Nigeria appears yet to fully embrace stunning, particularly penetrative percussive stunning, even though some workers $[62,63]$ have reported this stunning type able to knock out the consciousness in slaughter animals with ease. Stress due to decreased pre-slaughter welfare conditions (no housing and harsh climatic conditions) observed in this study can lower the immune status of slaughter cattle. This situation can aid the acquisition and dissemination of economically important livestock diseases, thereby worsening the already precarious welfare condition of the animals [64-66]. This is where and why the age of the cattle and season of slaughter remains very crucial. In addition, the humane pre-slaughter handling is key to preventing an abrupt increase in the rate of $\mathrm{pH}$ decline at the early phases of postmortem, because this situation can greatly affect both physiochemical and sensory qualities of the meat $[7,56,67,68]$. For instance, the water-holding capacity (WHC) is a key index of meat that demonstrates the ability of post-mortem muscle to retain moisture despite external pressures (cooking/heating, gravity). Moreover, pre-slaughter stress or exhaustion increases heart and respiratory rates, including muscle metabolic activities. This situation will deplete the muscle glycogen available for enzymatic conversion to lactic acid in the meat tissue, which is required to optimise the post-mortem $\mathrm{pH}$ (5.5-5.7) [69-72], prolong the shelf life, and limit microbial spoilage. Humane pre-slaughter practices would improve the sensory qualities of meat such as tenderness (or texture), juiciness and flavour [73,74].

A number of poor pre-slaughter practices were noted in this study. These included dragging, strangulation and excessive beating, which can increase the levels of creatine kinase (CK) and aspartate aminotransferase (AST) in meat. These enzyme markers are indicative of muscle damage and low meat quality, due to their adverse effects on meat colour (appearance), taste, and other quality indicators [75]. Agbeniga and Webb [76] reported that reducing both anxiety/stress and pre-slaughter stunning enhanced bleedout, decreased blood retention in the trachea, as well as blood splash in the lungs, which prolonged the meat shelf-life quality and limited the proliferation of spoilage bacteria. Enhanced bleed-out during slaughter is cardinal to food safety, as it limits microbial meat spoilage. Inefficient bleeding during slaughter owing to shock or fright-induced vasoconstriction can withhold blood in edible tissues [77], which facilitates meat decomposition and spoilage bacteria proliferation [78]. Further, high tissue cortisol level caused by preslaughter stress also facilitates lipid oxidation and activities of autolysis enzymes, which would enhance putrefaction or formation of PSE meat, even under storage (refrigeration or frozen) conditions $[1,12,78,79]$.

As per the welfare of the foetuses, the scientific debate has been on-going, for and against the bridge of AW inherent in foetal wastages as a result of the SPCs. The contentions focus on whether a foetus can perceive pain during maternal slaughter, and if so, at what stage of gestation does the pain perception begin. While the EFSA [80] affirmed that foetuses do not feel pain during the first and second trimesters, as the relevant physical and neurological structures only develop during the third trimester, there are expert opinions that suggest there could be between a $1 \%-33 \%$ likelihood that foetuses may experience pain during the last stage of gestation (third trimester). Corroborating this, recent expert opinions from the field of developmental neuroscience suggest that pain perception in foetuses may even start earlier than might have been previously thought. Derbyshire and Bockmann [81] reported that the brain cortex and the associated tracts, which are responsible for pain perception, could develop and emerge functional during the latter phase of the second trimester. Despite this, the "foetal pain" may be sub-cortically based, even though the relatively undifferentiated experiences of discomfort may be due to neural processing at levels below the cerebral cortex [82]. For actual pain perception to occur, the foetus needs to be both sentient and conscious [83]. During the gestational life, foetuses are maintained in a sleep-like unconscious mode through the activities of neuro-inhibitors [83]. Consciousness only appears after birth following a substantial withdrawal of the neuroinhibitors particularly adenosine $[83,84]$. This unconscious state makes pain perception in 
the foetus most unlikely. This implies that on event of unforeseen death of the dam, the foetus simply passes from the unconscious state to death with no or minimal pain. This argument, however, does not justify the unapproved slaughter of pregnant animals.

The high rate $(17.4 \%)$ at which pregnant cows were slaughtered and foetuses recovered (Tables 4 and 5) shown in this current study is rather surprising. This suggests that AW awareness in the study area appears to be low. With the exception of the SPCs, on the grounds of animal health and other welfare considerations, as may be approved by a veterinarian on ethical grounds, maternal slaughter on the basis of increased meat demand connotes cruelty and is hence unacceptable. It appears that the slaughter of gravid cows and the associated welfare issues is not restricted to Nigeria, as SPCs have been reported in more advanced countries such as the UK [85], Germany [86] and more recently in Denmark [87]. However, the magnitude of the practice and the reasons for the slaughter may vary from place to place. While the EFSA [80] reported that an average of $3 \%$ of dairy cows, and $1.5 \%$ of beef cattle slaughtered in the EU were in their last stage of gestation, our findings shows that $43.2 \%$ of pregnant cows slaughtered were at their third trimester. The slaughter of terminally gravid cows is worrisome, as pregnancies at the third trimester of gestation should be detected with ease, even by visual assessment. The slaughter of pregnant cows/heifers at the latter stages of pregnancy, as found in this work (Table 5), agrees with the findings of Wosu [40], in which $74 \%$ of pregnant cows slaughtered were in their second or third trimesters. This destructive practice does not only indicate animal cruelty but also threatens the development or growth of the livestock industry through excessive off-takes, depletion of the future herd, as well as loss of good genetic traits [88].

In the current study, SPCs within six months would lead to an estimated beef loss of about $44,000 \mathrm{~kg}$, which would be equivalent to about 70.1 million or $\$ 186,400$, with consequential foetal wastage. If this were to be replicated nationwide across slaughterhouses, there could be an estimated loss of about 4.3 tons of beef, equivalent to about $\$ 8.6$ billion or $\$ 23$ million. Further, if SPCs are allowed to persist unabated, the already precarious situation of acute animal protein shortfall in the country may worsen. This is because the 21 million cattle in the country, with an average annual growth rate of $1.85 \%$ [89], may not provide all the beef and dairy needs of approximately 210 million Nigerians with a population growth rate of $3.5 \%$ per annum [26]. Given that most developing countries are yet to achieve self-sufficiency in beef production [90], it is mind blowing to imagine the colossal loss of 4.3 tons of beef or 8.6 billion (\$23 million) due to SPCs and the resultant BFW. These avoidable losses are major setbacks to food security and economic development, in a country where meat supply grossly lags behind the demand [91].

Apart from the losses and the inherent economic wastages, SPCs may facilitate the spread of zoonotic pathogens inhabiting the reproductive tract of cows. Brucella and Leptospira organisms inhabit the reproductive and urinary tracts. Zoonotic transmission of brucellosis in abattoirs is possible via direct contact with placenta, eviscerated foetuses, uterine secretions or afterbirth materials from infected animals [92-95]. Leptospira infection can result from direct or indirect exposure to body fluids (urine) from the reproductive or urinary tracts of an infected animal [96,97], especially during abattoir meat processing. During the dressing or gutting of an infected animal, the contamination of the processed meat as well as the infection of the slaughterhouse workers would most likely be inevitable, if slaughterhouse workers do not wear personal protective equipment during routine operations [98]. It is also possible for the abattoir environment to be contaminated with the zoonotic organisms from food animals grazing around infected areas, which become onward transmissions of the pathogens to humans. This can apply to eviscerated foetuses discarded by unconventional methods (Table 6), which can aid environmental contamination and disease spread.

In all ramifications, the conduct of SPCs for meat would not be profitable. Herders, who may have erroneously culled their cows for infertility reasons, probably due to poor proficiency in pregnancy detection, would be at a loss. The butchers and beef sellers are equally at loss, as pregnant animals, especially those in their late stage of pregnancy, yield 
less meat than non-pregnant ones $[87,99,100]$. Further, the quality of meat from pregnant animals is doubtful. Meats sourced from pregnant animals are watery, have high $\mathrm{pH}$ and peak shear force values, poor eye appeal and also smell and tastes abnormal, due to high progesterone tissue levels $[100,101]$. In order to remedy the problem of slaughtering pregnant cows, decisive steps should be taken to provide trained personnel who are proficient in pregnancy diagnosis at the slaughterhouses. One major step in this regard is the engagement of more veterinarians and other trained animal health workers as meat inspectors and animal attendants, respectively. In Nigeria, the local and state governments have the responsibility to oversee and regulate the operations of slaughterhouses domiciled in their locality; however, some governments have contracted the oversight and regulatory functions to privately owned organisations. As a result, ante-mortem inspections, including pregnancy diagnosis in female animals intended for slaughter, have been reduced to mere collection of revenue per animal slaughtered [102,103]. To worsen the problem, veterinarians, who by training are competent on pregnancy and disease diagnosis in animals, are hardly employed by the contractors, probably to save costs. This development may have resulted in the high rate of SPCs being reported, and should be reversed by engagement of trained personnel at the abattoirs to improve the welfare conditions of slaughter-cattle and halt the SPCs.

Seasonality in the SPCs demonstrated herein (Table 3) could be a useful clue exploitable for effective control of AW challenges during the dry/hot seasons. A huge quantity of animal feed could be stocked and sold off to livestock farmers during draught and/or festive periods, at a subsidised rate, as an incentive to prevent sale or slaughter of gravid cows for meat. Significant loss of body conditions, as a result of drought-related food and water scarcities during the dry/hot season, usually compels livestock owners to salvage their animals by selling them off, irrespective of their pregnancy status $[89,104]$. Additionally, diversification of meat production through intensification of poultry production and other food animals could lessen the increased meat demand during festive periods, which usually prompts livestock farmers to sell off their animals, including pregnant ones, as buyers tend to offer higher prices. On the part of livestock farmers, there is a need for supervised breeding (especially in outdoor/extensive farming systems), proper recording of all breeding activities and routine on-farm pregnancy testing. This will help to limit farmers' ignorance on the pregnancy status of their animals, which was one of the major factors underpinning the sale of SPCs for meat (Table 2). In this regard, farmers' training and retraining of abattoir workers on some on-farm and rapid pregnancy diagnostic methods will be a step in the right direction. Also, massive public enlightenment campaigns on AW and the need to curtail the SPCs for meat is recommended, since the welfare of animals, particularly slaughter-cattle, is not prioritised in most developing countries.

\section{Concluding Remarks}

The slaughter of pregnant cows (SPCs) and its implications on the meat quality and food safety/security has been examined in this current study. Of the 851 cows, $17.4 \%$ $(148 / 851)$ were pregnant while $43.2 \%(64 / 148)$ of the total foetuses recovered were in their third trimester. The finding that $17.4 \%$ of the cows slaughtered for meat were pregnant is unacceptably high from AW and animal production perspectives. The high rate $(17.4 \%)$ at which pregnant cows was slaughtered is rather surprising, and suggests that AW awareness in the study area appears low. In this study, SPCs within six months would estimate beef loss amounting to $44,000 \mathrm{~kg}$, which would be equivalent to 70.1 million or $\$ 186,400$, with consequential foetal wastages. Despite this, the SPCs for meat is unprofitable in all ramifications, and its seasonality demonstrated herein could be useful clue for effective control of AW challenges in slaughterhouses in South-East Nigeria.

Strict implementation of the provisions of the Meat Edict of 1968 and Animal Disease (Control) Act of 2004, including humane slaughter and the prohibition of slaughter of PFAs, remains imperative. In fact, an amendment of the laws or enactment of the Nigerian Animal Welfare Strategy Framework drafted in 2016 in line with the present day AW 
issues, particularly at the slaughterhouses, is long overdue. Incorporating compulsory pregnancy diagnosis of all slaughter female animals in the ante-mortem inspection protocol is warranted. Proper labelling of meats obtained from pregnant animals, to guide buyers' discretion, should be mandatory. Slaughter facilities and persons defaulting on the issue of humane slaughter practices should be publicly reprimanded to deter others from doing the same. Overall, SPCs for meat and inhumane slaughter practices at the slaughterhouse should be prevented, to enhance the welfare needs of slaughter cattle, grow the national herd size, and improve meat safety as well as food security in Nigeria.

Author Contributions: Conceptualisation, U.J.N., E.O.N., O.C.N., H.O.E.; Data curation, U.J.N., O.C.N., F.O.A., F.E.A., N.A., A.B., A.K.U., C.O.R.O., M.K., R.P.F.G.; Literature search/synthesis, U.J.N., E.O.N., O.C.N., F.O.A., H.O.E., F.E.A., C.O.R.O.; Software, O.C.N., F.O.A., F.E.A., N.A., A.B., A.K.U.; Formal analysis, U.J.N., E.O.N., H.O.E., F.E.A., N.A., A.K.U.; Creation of figures, E.O.N., N.A., C.O.R.O.; Project administration, E.O.N., F.O.A., C.O.R.O., M.K., R.P.F.G.; Methodology, U.J.N., E.O.N., F.E.A., N.A., C.O.R.O.; Funding acquisition, C.O.R.O., M.K. and R.P.F.G.; Supervision, E.O.N., C.O.R.O., M.K., R.P.F.G.; Validation, O.C.N., F.O.A., H.O.E., F.E.A., A.K.U., A.B., C.O.R.O., M.K., R.F.P.G.; Visualisation, O.C.N., N.A., A.B., A.K.U., C.O.R.O., M.K., R.P.F.G.; Writing-original draft, U.J.N., E.O.N., O.C.N., F.O.A., N.A., H.O.E.; Writing-review and editing, A.B., A.K.U., C.O.R.O., M.K., R.P.F.G. All authors have read and agreed to the submitted version of the manuscript.

Funding: Publication financed by the project UPWR 2.0: international and interdisciplinary programme of development of Wrocław University of Environmental and Life Sciences, co-financed by the European Social Fund under the Operational Program Knowledge Education Development, under contract no. POWR.03.05.00-00-Z062/18 of 4 June 2019.

Institutional Review Board Statement: Not applicable.

Informed Consent Statement: All slaughterhouse workers provided their informed consent orally and individually prior to participation in this current survey.

Data Availability Statement: Data sharing not applicable.

Acknowledgments: The authors A.B., C.O.R.O. and M.K. acknowledge financial support from the Wrocław University of Environmental and Life Sciences, Poland. The author R.P.F.G. acknowledges financial support from the Polytechnic Institute of Viseu, Portugal.

Conflicts of Interest: The authors declare no conflict of interest.

\section{References}

1. Xing, T.; Gao, F.; Tume, R.K.; Zhou, G.; Xu, X. Stress Effects on Meat Quality: A Mechanistic Perspective. Compr. Rev. Food Sci. Food Saf. 2019, 18, 380-401. [CrossRef] [PubMed]

2. Cevallos-Almeida, M.; Burgos-Mayorga, A.; Gómez, C.A.; Lema-Hurtado, J.L.; Lema, L.; Calvache, I.; Jaramillo, C.; Ruilova, I.C.; Martínez, E.P.; Estupiñán, P. Association between animal welfare indicators and microbiological quality of beef carcasses, including Salmonella spp., from a slaughterhouse in Ecuador. Veter. World 2021, 14, 918-925. [CrossRef]

3. Okpala, C.; Nwobi, O.; Korzeniowska, M. Assessing Nigerian Butchers' Knowledge and Perception of Good Hygiene and Storage Practices: A Cattle Slaughterhouse Case Analysis. Foods 2021, 10, 1165. [CrossRef] [PubMed]

4. McCleery, D.R.; Stirling, J.M.E.; McIvor, K.; Patterson, M.F. Effect of ante-and postmortem hide clipping on the microbiological quality and safety and ultimate $\mathrm{pH}$ value of beef carcasses in an EC-approved abattoir. J. Appl. Microbiol. 2008, 104, 1471-1479. [CrossRef]

5. Węglarz, A. Meat quality defined based on $\mathrm{pH}$ and colour depending on cattle category and slaughter season. colour and $\mathrm{pH}$ as determinants of meat quality dependent on cattle category and slaughter season. Czech. J. Anim. Sci. 2010, 55, 548-556. [CrossRef]

6. Weglarz, A. Effect of pre-slaughter housing of different cattle categories on beef quality. Anim. Sci. Pap. Rep. 2011, $29,43-52$.

7. Abubakar, A.; Zulkifli, I.; Goh, Y.; Kaka, U.; Sabow, A.; Imlan, J.; Awad, E.; Othman, A.; Raghazli, R.; Mitin, H.; et al. Effects of Stocking and Transport Conditions on Physicochemical Properties of Meat and Acute-Phase Proteins in Cattle. Foods 2021, 10, 252. [CrossRef]

8. Delgado, H.; Cedeño, C.; de Ocaii, N.M.; Villoch, A. Hygienic quality of the meat obtained at slaughterhouses in Manabí- Ecuador. J. Anim. Health 2015, 37, 1-9.

9. Yenealem, D.G.; Yallew, W.W.; Abdulmajid, S. Food Safety Practice and Associated Factors among Meat Handlers in Gondar Town: A Cross-Sectional Study. J. Environ. Public Health 2020, 2020, 7421745. [CrossRef]

10. Bautista, J.H.; De Oaxaca, M.U.A.B.J.; López, J.L.A.; Rincón, F.G.R. Pre-mortem handling effect on the meat quality. Nacameh 2013, 7, 41-64. [CrossRef] 
11. Sinclair, M.; Fryer, C.; Phillips, C.J.C. The Benefits of Improving Animal Welfare from the Perspective of Livestock Stakeholders across Asia. Animal 2019, 9, 123. [CrossRef] [PubMed]

12. Food and Agricultural Organisation of the United Nations (FAO). Effects of Stress and Injury on Meat and by-Product Quality. Available online: http:/ / www.fao.org/3/x6909e/x6909e04.htm (accessed on 10 April 2020).

13. Sheridan, J. Sources of contamination during slaughter and measures for control. J. Food Saf. 1998, 18, 321-339. [CrossRef]

14. Njisane, Y.Z.; Muchenje, V. Farm to abattoir conditions, animal factors and their subsequent effects on cattle behavioural responses and beef quality-A review. Asian Australas. J. Anim. Sci. 2016, 30, 755-764. [CrossRef]

15. Fernandes, J.; Hemsworth, P.; Coleman, G.; Tilbrook, A. Costs and Benefits of Improving Farm Animal Welfare. Agriculture 2021, 11, 104. [CrossRef]

16. Grandin, T. Auditing animal welfare at slaughter plants. Meat Sci. 2010, 86, 56-65. [CrossRef]

17. Food and Agricultural Organisation of the United Nations (FAO). Slaughter of Livestock. Available online: http://www.fao.org/ 3/x6909e/x6909e09.htm (accessed on 24 January 2021).

18. American Veterinary Medical Association (AVMA). Animal Welfare: What Is It? Available online: https://www.avma.org/ resources/animal-health-welfare/animal-welfare-what-it (accessed on 5 April 2021).

19. OIE (World Organization for Animal Health). Chapter 7.1. Introduction to the Recommendations for Animal Welfare. Terrestrial Animal Health Code 2010. Available online: http:/ / www.oie.int/index.php?id=169\&L=0\&htmfile=chapitre_1.7.1.htm (accessed on 21 February 2021).

20. Brown, M.J.; Winnicker, J.; Animal Welfare. American College of Laboratory Animal Medicine, Laboratory Animal Medicine, 3rd ed.; Fox, J.G., Anderson, L.C., Otto, G., Pritchett-Corning, K.R., Whary, M.T., Eds.; Academic Press: Cambridge, MA, USA, 2015; pp. 1653-1672. [CrossRef]

21. Iannetti, L.; Neri, D.; Santarelli, G.A.; Cotturone, G.; Vulpiani, M.P.; Salini, R.; Antoci, S.; Di Serafino, G.; Di Giannatale, E.; Pomilio, F; i et al. Animal welfare and microbiological safety of poultry meat: Impact of different at-farm animal welfare levels on at-slaughterhouse Campylobacter and Salmonella contamination. Food Control. 2020, 109, 106921. [CrossRef]

22. Mshelia, G.; Maina, V.; Aminu, M. Foetometrics and Economic Impact Analysis of Reproductive Wastages in Ruminant Species Slaughtered in North-Eastern Nigeria. J. Anim. Prod. Adv. 2015, 5, 1. [CrossRef]

23. Odeh, S.; Dawuda, P.M.; Oyedipe, E.O.; Obande, G.E. Incidence of foetal wastage in slaughtered cattle at Wurukum abattoir, Makurdi, Benue State. Vom. J. Vet. Sci. 2015, 10, 41-50.

24. Adebowale, O.O.; Ekundayo, O.; Awoseyi, A. Female cattle slaughter and foetal wastage: A case study of the Lafenwa abattoir, Ogun state, Nigeria. Cogent Food Agric. 2020, 6, 6. [CrossRef]

25. Abonyi, F.O.; Njoga, E.O. Prevalence and determinants of gastrointestinal parasite infection in intensively managed pigs in Nsukka agricultural zone, Southeast, Nigeria. J. Parasit. Dis. 2020, 44, 31-39. [CrossRef]

26. Worldometer, Nigerian Population. Available online: https://www.worldometers.info/world-population/nigeria-population/ (accessed on 4 April 2021).

27. Algers, B. Animal welfare-recent developments in the field. CAB Rev. Perspect. Agric. Veter. Sci. Nutr. Nat. Resour. 2011, 6, 1-10. [CrossRef]

28. Burroughs, T.; Knobler, S.; Lederberg, J. (Eds.) The Importance of Zoonotic Diseases. In The Emergence of Zoonotic Diseases: Understanding the Impact on Animal and Human Health: Workshop Summary; National Academies Press: Washington, DC, USA, 2002. Available online: https:/ / www.ncbi.nlm.nih.gov/books/NBK98094 (accessed on 14 March 2021).

29. Njoga, E.O.; Ariyo, O.E.; Nwanta, J.A. Ethics in veterinary practice in Nigeria: Challenges and the way-forward. Niger. Vet. J. 2019, 40, 85-93. [CrossRef]

30. Baer-Nawrocka, A.; Sadowski, A. Food security and food self-sufficiency around the world: A typology of countries. PLoS ONE 2019, 14, e0213448. [CrossRef] [PubMed]

31. Brown, P.; Will, R.G.; Bradley, R.; Asher, D.M.; Detwiler, L. Bovine Spongiform Encephalopathy and Variant Creutzfeldt-Jakob Disease: Background, Evolution, and Current Concerns. Emerg. Infect. Dis. 2001, 7, 6-16. [CrossRef]

32. Henchion, M.; Hayes, M.; Mullen, A.M.; Fenelon, M.; Tiwari, B. Future Protein Supply and Demand: Strategies and Factors Influencing a Sustainable Equilibrium. Foods 2017, 6, 53. [CrossRef] [PubMed]

33. Cadmus, S.I.; Adesokan, H.K. Bovine fetal wastage in Southwestern Nigeria: A survey of some abattoirs. Trop. Anim. Health Prod. 2010, 42, 617-621. [CrossRef]

34. Salami, S.O.; Raji, M.A.; Ameh, J.A. Foetal wastages through slaughtering of pregnant cows in Zaria, Nigeria. Sahel J. Vet. Sci. 2010, 9, 21-24.

35. Iliyasu, D.; Ogwu, D.; Yelwa, H.; Yaroro, I.; Ayinla, A.; Usman, A.; Sharadi, B.; Grace, K. Incidence of Bovine pregnancy wastage in Maiduguri abattoir, Borno State Nigeria. Int. J. Livest. Res. 2015, 5, 59. [CrossRef]

36. Amuta, P.O.; Tordue, K.A.; Kudi, C.A.; Mhomga, L.I. Economic Implication of Foetal Wastages through Slaughter of Pregnant Pigs: A Case Study of the Makurdi Municipal Abattoir in Benue State, Nigeria. Asian J. Res. Anim. Vet. Sci. 2018, 1, 1-8.

37. Anyaku, C.E.; Ajagun, E.J.; Oshagbemi, A.O. Foetal Wastage at the Oja-tuntun Slaughterhouse in Ogbomoso Town, South Western Nigeria: A Three Year Retrospective Study. Asian J. Res. Zoo 2019, 2, 1-7. [CrossRef]

38. Odoemena, K.G.; Walters, J.P.; Kleemann, H.M.A. System Dynamics Model of Supply-Side Issues Influencing Beef Consumption in Nigeria. Sustainability 2020, 12, 3241. [CrossRef] 
39. Vries-Ten Have, J.; Owolabi, A.; Steijns, J.; Kudla, U.; Melse-Boonstra, A. Protein intake adequacy among Nigerian infants, children, adolescents and women and protein quality of commonly consumed foods. Nutr. Res. Rev. 2020, 33, 102-120. [CrossRef] [PubMed]

40. Wosu, L. Calf wastage through slaughtering of pregnant cows in Enugu abattoir, Nigeria. Rev. Elev. Med. Vet. Pays Trop. Fr. 1988, 41,97-98.

41. Nwanta, J.A.; Shoyinka, S.V.O.; Chah, K.F.; Onunkwo, J.I.; Onyenwe, I.W.; Eze, J.I.; Iheagwam, C.N.; Njoga, E.O.; Onyema, I.; $\mathrm{Ogbu}$, K.I.; et al. Production characteristics, disease prevalence, and herd health management of pigs in Southeast Nigeria. J. Swine Health Prod. 2011, 19, 331-339.

42. Anonymous. Climate of Nigeria. Available online: https://www.britannica.com/place/Nigeria/Climate (accessed on 11 April 2021).

43. Worldometers. Nigeria Population in 2019. Available online: http://www.worldometers.info/world-population/nigeriapopulation/ (accessed on 22 January 2021).

44. Holmes, A. Direct Observation. In Encyclopedia of Autism Spectrum Disorders; Volkmar, F.R., Ed.; Springer: New York, NY, USA, 2013. [CrossRef]

45. Nwanta, J.A.; Onunkwo, J.I.; Ezenduka, E.V.; Phil-Eze, P.O.; Egege, S.C. Abattoir operations and waste management in Nigeria: A review of challenges and prospects. Sokoto J. Vet. Sci. 2008, 7, 61-67.

46. World Medical Association (WMA). World Medical Association Declaration of Helsinki: Ethical principles for medical research involving human subjects. JAMA 2013, 310, 2191-2194. [CrossRef]

47. Pourhoseingholi, M.A.; Vahedi, M.; Rahimzadeh, M. Sample size calculation in medical studies. Gastroenterol. Hepatol. Bed Bench 2013, 6, 14-17.

48. Bolarinwa, O.A. Principles and methods of validity and reliability testing of questionnaires used in social and health science researches. Niger. Postgrad. Med. J. 2015, 22, 195-201. [CrossRef] [PubMed]

49. Pace, J.E.; Wakeman, D.L. Determining the Age of Cattle by Their Teeth, University of Florida, IFAS Extension. 2003. Available online: http:/ / www.edis.ifas.ufl.edu (accessed on 11 April 2020).

50. Kouamo, J.; Saague, A.M.N.; Zoli, A.P. Determination of age and weight of bovine foetus (Bos indicus) by biometry. J. Livest. Sci. 2018, 9, 9-15.

51. PennState Extension. Understanding Beef Carcass Yields and Losses During Processing. Available online: https: / / extension.psu. edu/understanding-beef-carcass-yields-and-losses-during-processing (accessed on 21 February 2021).

52. Ndi, C.; Tambi, N.E.; Agharih, N.W. Reducing Calf Wastage from Slaughtering of Pregnant Cows in Cameroon. Available online: http: / / www.fao.org/documents /art_dett.asp?lang=en\&art_id=54949 (accessed on 21 May 2020).

53. Crowson, P. Price Determination. In Economics for Managers; Palgrave Macmillan: London, UK, 1985. [CrossRef]

54. Frimpong, S.; Gebresenbet, G.; Bobobee, E.; Aklaku, E.D.; Hamdu, I. Effect of Transportation and Pre-Slaughter Handling on Welfare and Meat Quality of Cattle: Case Study of Kumasi Abattoir, Ghana. Vet. Sci. 2014, 1, 174-191. [CrossRef]

55. Huertas, S.M.; van Eerdenburg, F.; Gil, A.; Piaggio, J. Prevalence of carcass bruises as an indicator of welfare in beef cattle and the relation to the economic impact. Vet. Med. Sci. 2015, 1, 9-15. [CrossRef]

56. Faucitano, L. Preslaughter handling practices and their effects on animal welfare and pork quality. J. Anim. Sci. 2018, 96, 728-738. [CrossRef] [PubMed]

57. European Commission (EC). Council Regulation No 1/2005 of 22 December 2004 on the Protection of Animals during Transport. and Related Operations and Amending Directives 64/432/EEC and 93/119/EC and Regulation (EC) No 1255/97; European Commission (EC): Brussels, Belgium, 2005.

58. Okaeme, A.; Ayeni, J.; Oyatogun, M.; Wari, M.; Haliru, M.; Okeyoyin, A. Cattle movement and its ecological implications in the Middle Niger Valley area of Nigeria. Environ. Conser. 1988, 15, 311-316. [CrossRef]

59. Lawal-Adebowale, O.A. Dynamics of ruminant livestock management in the context of the Nigerian agricultural system. In Livestock Production; IntechOpen: London, UK, 2012. [CrossRef]

60. FAO. The Future of Livestock in Nigeria: Opportunities and Challenges in the Face of Uncertainty; Food and Agricultural Organization of the United Nations: Rome, Italy, 2019. Available online: http://www.fao.org/3/ca5464en/ca5464en.pdf (accessed on 28 January 2021).

61. Omotosho, O.O.; Emikpe, B.O.; Lasisi, O.T.; Oladunjoye, O.V. Pig slaughtering in Southwestern Nigeria: Peculiarities, animal welfare concerns and public health implications. Afr. J. Infect. Dis. 2016, 10, 146-155. [CrossRef]

62. Nakyinsige, K.; Man, Y.B.C.; Aghwan, Z.A.; Zulkifli, I.; Goh, Y.M.; Bakar, F.A.; Al-Kahtani, H.A.; Sazili, A.Q. Stunning and animal welfare from Islamic and scientific perspectives. Meat Sci. 2013, 95, 352-361. [CrossRef]

63. Abdullah, F.; Borilova, G.; Steinhauserova, I. Halal criteria versus conventional slaughter technology. Animals 2019, 9, 530. [CrossRef] [PubMed]

64. Oloruntoba, E.O.; Adebayo, A.M.; Omokhodion, F.O. Sanitary conditions of abattoirs in Ibadan, Southwest Nigeria. Afr. J. Med. Med. Sci. 2014, 43, 231-237. [PubMed]

65. Biobaku, K.T.; Amid, S.A. Predisposing factors associated with diseases in animals in Nigeria and possible botanical immunostimulants and immunomodulators: A review. BJVM 2018, 16, 87-101. [CrossRef]

66. Dahl, G.E.; Tao, S.; Laporta, J. Heat stress impacts immune status in cows across the life cycle. Front. Vet. Sci. 2020, 7, 116. [CrossRef] [PubMed] 
67. Huff-Lonergan, E.; Lonergan, S.M. Mechanisms of water-holding capacity of meat: The role of postmortem biochemical and structural changes. Meat Sci. 2005, 71, 194-204. [CrossRef] [PubMed]

68. Huff-Lonergan, E. Fresh meat water-holding capacity. In Woodhead Publishing Series in Food Science, Technology and Nutrition, Improving the Sensory and Nutritional Quality of Fresh Meat; Kerry, J.P., Ledward, D., Eds.; Woodhead Publishing: Cambridge, UK, 2009; pp. 147-160. [CrossRef]

69. Chulayo, A.Y.; Tada, O.; Muchenje, V. Research on pre-slaughter stress and meat quality: A review of challenges faced under practical conditions. Appl. Anim. Husb. Rural Develop. 2012, 5, 1-6.

70. Brewer, M.S. Chemical and Physical Characteristics of Meat I Water-Holding Capacity. Encyclopedia of Meat Sciences, 2nd ed.; Dikeman, M., Devine, C., Eds.; Academic Press: Cambridge, MA, USA, 2014; pp. 274-282. [CrossRef]

71. Birhanu, A.F. Review on Beef Cattle Pre-slaughter Stress and Its Effect on Meat and Carcass Quality. Adv. Life Sci. Technol. 2020, 78. [CrossRef]

72. Ponnampalam, E.N.; Hopkins, D.L.; Bruce, H.; Li, D.; Baldi, G.; Bekhit, A.E.-D. Causes and Contributing Factors to “Dark Cutting” Meat: Current Trends and Future Directions: A Review. Compr. Rev. Food Sci. Food Saf. 2017, 16, 400-430. [CrossRef] [PubMed]

73. López-Pedrouso, M.; Rodriguez, J.M.L.; Purriños, L.; Oliván, M.; García-Torres, S.; Sentandreu, M.Á.; Lorenzo, J.M.; Zapata, C.; Franco, D. Sensory and Physicochemical Analysis of Meat from Bovine Breeds in Different Livestock Production Systems, Pre-Slaughter Handling Conditions, and Ageing Time. Foods 2020, 9, 176. [CrossRef]

74. Terlouw, E.M.C.; Picard, B.; Deiss, V.; Berri, C.; Hocquette, J.-F.; Lebret, B.; Lefèvre, F.; Hamill, R.; Gagaoua, M. Understanding the Determination of Meat Quality Using Biochemical Characteristics of the Muscle: Stress at Slaughter and Other Missing Keys. Foods 2021, 10, 84. [CrossRef]

75. Loudon, K.M.; Tarr, G.; Lean, I.J.; Polkinghorne, R.; McGilchrist, P.; Dunshea, F.R.; Gardner, G.E.; Pethick, D.W. The Impact of Pre-Slaughter Stress on Beef Eating Quality. Animal 2019, 9, 612. [CrossRef]

76. Agbeniga, B.; Webb, E. Effect of slaughter technique on bleed-out, blood in the trachea and blood splash in the lungs of cattle. S. Afr. J. Anim. Sci. 2012, 42, 524-529. [CrossRef]

77. Addis, M. Major Causes Of Meat Spoilage and Preservation Techniques: A Review. Food Sci. Qual. Manag. 2015, 41, 101-114.

78. Nakyinsige, K.; Fatimah, A.B.; Aghwan, Z.A.; Zulkifli, I.; Goh, Y.M.; Sazili, A.Q. Bleeding Efficiency and Meat Oxidative Stability and Microbiological Quality of New Zealand White Rabbits Subjected to Halal Slaughter without Stunning and Gas Stun-killing. Asian Australas. J. Anim. Sci. 2014, 27, 406-413. [CrossRef] [PubMed]

79. Luong, N.-D.M.; Coroller, L.; Zagorec, M.; Membré, J.-M.; Guillou, S. Spoilage of Chilled Fresh Meat Products during Storage: A Quantitative Analysis of Literature Data. Microorganisms 2020, 8, 1198. [CrossRef]

80. EFSA. Scientific opinion on the animal welfare aspects in respect of the slaughter or killing of pregnant livestock animals (cattle, pigs, sheep, goats, horses). EFSA J. 2017, 15, 4782. [CrossRef]

81. Derbyshire, S.W.; Bockmann, J.C. Reconsidering fetal pain. J. Med. Ethics. 2020, 46, 3-6. [CrossRef] [PubMed]

82. Campbell, M.L.; Mellor, D.J.; Sandøe, P. How should the welfare of fetal and neurologically immature postnatal animals be protected? Anim. Welf. 2014, 23, 369-379. [CrossRef] [PubMed]

83. Mellor, D.J.; Diesch, T. Onset of sentience: The potential for suffering in fetal and newborn farm animals. Appl. Anim. Behav. Sci. 2006, 100, 48-57. [CrossRef]

84. Mellor, D.J. Galloping colts, fetal feelings, and reassuring regulations: Putting animal-welfare science into practice. J. Vet. Med. Educ. 2010, 37, 94-100. [CrossRef]

85. Singleton, G.H.; Dobson, H. A survey for the reasons for culling pregnant cows. Vet. Rec. 1995, 136, 162-165. [CrossRef]

86. Maurer, P.; Lücker, E.; Riehn, K. Slaughter of pregnant cattle in German abattoirs-Current situation and prevalence: A crosssectional study. BMC Vet. Res. 2016, 12, 91. [CrossRef] [PubMed]

87. Nielsen, S.S.; Sandøe, P.; Kjølsted, S.U.; Agerholm, J.S. Slaughter of pregnant cattle in Denmark: Prevalence, gestational age, and reasons. Animals 2019, 9, 392. [CrossRef] [PubMed]

88. Fayemi, P.O.; Muchenje, V. Maternal slaughter at abattoirs: History, causes, cases and the meat industry. SpringerPlus 2013, 2, 125. [CrossRef] [PubMed]

89. Dunka, H.I.; Buba, D.M.; Gurumyen, Y.G.; Oragwa, A.O.; Oziegbe, S.D.; Patrobas, M.N. Economic losses associated with the slaughter of pregnant animals in Jos abattoir. Int. J. Adv. Res. 2017, 5, 1047-1052.

90. FAO. Current Worldwide Annual Meat Consumption, Per Capita, Livestock and Fish Primary Equivalent. Available online: http:/ / faostat.fao.org (accessed on 14 December 2018).

91. Njoga, E.O.; Onunkwo, J.I.; Chinwe, C.E.; Ugwuoke, W.; Nwanta, J.A.; Chah, K.F. Assessment of antimicrobial drug administration and antimicrobial residues in food animals in Enugu State, Nigeria. Trop. Anim. Health Prod. 2018, 50, 897-902. [CrossRef]

92. Aworh, M.K.; Okolocha, E.; Kwaga, J.; Fasina, F.; Lazarus, D.; Suleman, I.; Poggensee, G.; Nguku, P.; Nsubuga, P. Human brucellosis: Seroprevalence and associated exposure factors among abattoir workers in Abuja, Nigeria-2011. Pan Afr. Med. J. 2013, 16, 103. [CrossRef]

93. Godfroid, J. Brucellosis in livestock and wildlife: Zoonotic diseases without pandemic potential in need of innovative one health approaches. Arch. Public Health 2017, 75, 34. [CrossRef]

94. Bamaiyi, P.H. Prevalence and risk factors of brucellosis in man and domestic animals: A review. Int. J. One Health 2016, 2, 29-34. [CrossRef] 
95. Awah-Ndukum, J.; Mouiche, M.M.M.; Kouonmo-Ngnoyum, L.; Bayang, H.N.; Manchang, T.K.; Poueme, R.S.N.; Kouamo, J.; Ngu-Ngwa, V.; Assana, E.; Feussom, K.J.M.; et al. Seroprevalence and risk factors of brucellosis among slaughtered indigenous cattle, abattoir personnel and pregnant women in Ngaoundéré, Cameroon. BMC Inf. Dis. 2018, 18. [CrossRef]

96. Swai, E.S.; Schoonman, L. A survey of zoonotic diseases in trade cattle slaughtered at Tanga city abattoir: A cause of public health concern. Asian Pac. J. Trop. Biomed. 2012, 2, 55-60. [CrossRef]

97. Guernier, V.; Goarant, C.; Benschop, J.; Lau, C.L. A systematic review of human and animal leptospirosis in the Pacific Islands reveals pathogen and reservoir diversity. PLoS Negl. Trop. Dis. 2018, 12, e000650. [CrossRef] [PubMed]

98. Ekere, S.O.; Njoga, E.O.; Onunkwo, J.I.; Njoga, U.J. Serosurveillance of Brucella antibody in food animals and role of slaughterhouse workers in spread of Brucella infection in Southeast Nigeria. Vet. World 2018, 11, 1171-1178. [CrossRef]

99. Nonga, H.E. A review on cattle foetal wastage during slaughter and its impacts to the future cattle herds in Tanzania. Livest. Res. Rural. Dev. 2015, 27. Available online: http://www.lrrd.org/lrrd27/12/nong27251.html (accessed on 21 February 2021).

100. Okorie-Kanu, O.J.; Ezenduka, E.V.; Okorie-Kanu, C.O.; Anyaoha, C.O.; Attah, C.A.; Ejiofor, T.E.; Onwumere-Idoloh, S.O. Slaughter of pregnant goats for meat at Nsukka slaughterhouse and its economic implications: A public health concern. Vet. World 2018, 11, 1139-1144. [CrossRef] [PubMed]

101. Wythes, J.R.; Shorthose, W.R.; Fordyce, G.; Underwood, D.W. Pregnancy effects on carcass and meat quality attributes of cows. Anim. Prod. Sci. 1990, 51, 461-468. [CrossRef]

102. Kalio, G.A.; Ali-Uchechukwu, A. Assessment of abattoirs operations and hygiene practices in Obio-Akpor Local Government Area, Rivers State, Nigeria. Niger. J. Anim. Prod. 2019, 46, 73-81. [CrossRef]

103. Gali, A.U.; Abdullahi, H.A.; Umaru, G.A.; Zailani, S.A.; Adamu, S.G.; Hamza, I.M.; Jibrin, M.S. Assessment of operational facilities and sanitary practices in Zangon Shanu abattoir, Sabon Gari Local Government Area, Kaduna State, Nigeria. J. Vet. Med. Anim. Health 2020, 12, 36-47. [CrossRef]

104. Madzingira, O. Animal welfare considerations in food-producing animals. In Animal Welfare; Abubakar, M., Manzoor, S., Eds.; IntechOpen: London, UK, 2018. [CrossRef] 